\title{
Condition and factors of development of the stock-raising industry in Uzbekistan
}

\author{
N.A. Ashurmetova* \\ Tashkent State Agrarian University, Tashkent, Uzbekistan
}

\begin{abstract}
This article analyzes the current state of the stock-raising industry in Uzbekistan and highlights the problems in this area. The study revealed that the livestock sector is quite developed in the republic, it accounts for $50.5 \%$ of agricultural products produced in the country. The main feature of the sector is that most of the livestock products are produced in small family (dekhkan) farms, which is of great social importance, since it is an important source of income and consumption for a significant number of families. However, the small size of the overwhelming majority of livestock farms determines limited opportunities for the effective development of the industry.
\end{abstract}

\section{Introduction}

Despite the pandemic of coronavirus infection, which led to a fundamental shift in the social order, as a result of the implementation of the priority tasks identified by the government of the Republic of Uzbekistan, the country has ensured sustainable development in almost all spheres of the economy. In particular, the implementation of program measures for the further reform and development of agriculture aimed at ensuring food security provided a solid basis for achieving positive indicators of agricultural development. [2.5] Thus, the volume of agricultural production amounted to 249.8 trillion soums, or $102.8 \%$ in relation to 2019 , including crop production reached 123.6 trillion soums (103.4\%), stockraising products - 126.2 trillion soums (102.1\%). [7]

The development of stock-raising is closely connected with the state and development of the agricultural sector of the economy. As an essential part of the agri-food market, livestock today provides markets with animal-based food and by-products, contributes significantly to maintaining living standards in rural areas, becoming an important source of nutrition and cash income for the rural population, and provides a range of ecosystem services such as conservation, restoration of biodiversity of pasture and fertility of arable lands.

It should be noted that in developed countries, stock-raising accounts for $40 \%$ of total agricultural production, in developing countries - $20 \%$. Animal products provide an average of $33 \%$ of the protein intake and $17 \%$ of the human calorie intake. [8] Fertilizers, biofuels, pharmaceuticals, feed, fur, leather products, etc. are obtained from animal by-products.

In Uzbekistan, the stock-raising sector is also of key importance, and in order to accelerate the development of the industry in the country, consistent measures are being taken on

\footnotetext{
* Corresponding author: janita06@mail.ru
} 
organizational changes and the introduction of an organizational structure for agricultural production that corresponds to market principles, the introduction of modern and innovative methods, an increase in the volume and expansion of the range of produced products, state support is provided to enterprises, specializing in stock-raising. Last two years, a number of legislative acts have been adopted aimed at creating conditions for the development of the industry, including the Decree of the President of the Republic of Uzbekistan dated on March 28, 2019 N UP-5696 "On measures to radically improve the system of public administration in the field of veterinary medicine and stock-raising", Resolution of the President of the Republic of Uzbekistan dated on March 18, 2019 N PP-4243 "On measures for further development and support of the stock-raising industry", Resolution of the President of the Republic of Uzbekistan dated on January 29, 2020 N PP-4576 "On additional measures of state support for the stock-raising industry" and others. A new impetus for the further development of the stock-raising market is the Strategy for the Development of Agriculture of the Republic of Uzbekistan for 2020-2030, in which the priority area is "Ensuring the Food Security of the Population". [1]

The aim of the study is to study the state of development of the stock-raising industry in Uzbekistan and identify problems in this area. To achieve this goal, a number of tasks are performed: an analysis of the state of the livestock industry is carried out; the factors that determine the effectiveness of the development of the industry are characterized; the factors of increasing the efficiency of stock-raising are summarized.

\section{Materials and methods}

The theoretical and methodological basis for studying the development of animal husbandry were the works of domestic and foreign scientists, specialists, an integrated systematic approach to the analysis of the processes under study, legislative and regulatory acts providing for the renewal of the agricultural sector of the economy. During the study of the state of development of the livestock industry, the economic and statistical method was used, as well as general methods of scientific knowledge: observation, analysis, comparison, generalization.

\section{Research results}

The production of stock-raising products in Uzbekistan is distinguished by its richness and diversity. Historically, each region of the republic has its own type of animal husbandry, for example, dairy cattle are raised mainly in an irrigated area near industrial centers; beef cattle - on pastures in mountainous areas; astrakhan sheep, camels - mainly in desert and steppe zones; pig and poultry industries are concentrated mainly near cities and industrial centers. There are many rich pastures in the mountains and foothills of the republic, where, in addition to cattle for meat and dairy production, sheep and fine-haired goats are raised. The stockraising sector of agriculture also includes horse breeding, beekeeping, silkworm breeding and fish farming. The main feature of the industry is that most of the stock-raising products are created in small family (dehkan) farms, for which land plots ranging from 0.06 hectares to 1 hectares are provided. [4]

According to the State Statistics Committee of the Republic of Uzbekistan, in 2020 all categories of farms produced 2526,2 thousand tons of meat in live weight, which is $2.1 \%$ more compared to 2019, 11009.9 thousand tons of milk (by 2.8\%), 7825.0 million eggs $(0.7 \%), 35.7$ thousand tons of wool $(1.5 \%)$ and 144,085 tons of fish $(18.4 \%)$. The volume of basic stock-raising products falls on dekhkan farms, including meat - 2277,1 thousand tons, or $90.1 \%$ of the total volume of its production, milk - 10386,4 thousand tons, or $94.3 \%$ of 
the total the volume of its production, eggs - 4579,8 million pieces, or $58.5 \%$ of the total volume of their production (Table 1).

Table 1. Production of the main types of stock-raising products in the republic [7]

\begin{tabular}{|l|c|c|c|c|c|}
\hline \multicolumn{7}{|c|}{ Production } & $\mathbf{2 0 1 6}$ & $\mathbf{2 0 1 7}$ & $\mathbf{2 0 1 8}$ & $\mathbf{2 0 1 9}$ & $\mathbf{2 0 2 0}$ \\
\hline \multicolumn{7}{|c|}{ All farm categories } \\
\hline Meat, thousand tons & 2172,5 & 2286,8 & 2430,5 & 2473,6 & 2526,2 \\
\hline Milk, thousand tons & 9703,4 & 10047,9 & 10466,4 & 10714,3 & 11009,9 \\
\hline Eggs, mln.pcs. & 6152,5 & 6332,7 & 7459,3 & 7771,2 & 7825,0 \\
\hline \multicolumn{7}{|c|}{ Farming enterprises } \\
\hline Meat, thousand tons & 62,2 & 69,3 & 109,5 & 125,7 & 130,9 \\
\hline Milk, thousand tons & 352,7 & 337,7 & 397,3 & 462,0 & 524,7 \\
\hline Eggs, mln.pcs. & 656,7 & 695,3 & 1079,5 & 1142,8 & 1135,0 \\
\hline \multicolumn{7}{|c|}{ Dehkan farms } \\
\hline Meat, thousand tons & 2051,3 & 2145,9 & 2236,5 & 2230,9 & 2277,1 \\
\hline Milk, thousand tons & 9278,8 & 9641,8 & 9995,8 & 10156,5 & 10386,4 \\
\hline Eggs, mln.pcs. & 3528,2 & 4020,8 & 4335,1 & 4491,5 & 4579,8 \\
\hline \multicolumn{7}{|c|}{ Organizations engaged in agricultural activities } \\
\hline Meat, thousand tons & 59,1 & 71,6 & 84,5 & 117,0 & 118,2 \\
\hline Milk, thousand tons & 71,9 & 68,4 & 73,3 & 95,8 & 98,8 \\
\hline Eggs, mln.pcs. & 1967,5 & 1616,6 & 2044,7 & 2136,8 & 2110,2 \\
\hline
\end{tabular}

In 2020, the total number of cattle reached 13188.7 thousand heads, including 4744.3 thousand cows, which is $1.8 \%$ and $1.7 \%$ more than in 2019 , respectively. Analysis of data on the number of cattle by categories of farms shows that the main keepers of all types of stockraising and poultry are dekhkan farms. They account for $92.8 \%$ of cattle, including $93.2 \%$ of cows, $81.4 \%$ of sheep and goats, $76.3 \%$ of horses and $58.9 \%$ of birds (Table 2 ).

Table 2. Change in the number of stock-raising for all categories of farms (thousand heads) [7]

\begin{tabular}{|l|c|c|c|c|c|}
\hline \multicolumn{7}{|c|}{$\mathbf{2 0 1 6}$} & $\mathbf{2 0 1 7}$ & $\mathbf{2 0 1 8}$ & $\mathbf{2 0 1 9}$ & $\mathbf{2 0 2 0}$ \\
\hline \multicolumn{7}{|c|}{ All farm categories } \\
\hline Cattle & 12181,4 & 12471,0 & 12814,1 & 12949,7 & 13188,7 \\
\hline incl. cows & 4217,3 & 4336,5 & 4626,0 & 4663,5 & 4744,3 \\
\hline Sheep and goats & 19697,9 & 20640,9 & 21580,5 & 21906,9 & 22498,6 \\
\hline Horses & 221,4 & 230,6 & 242,5 & 247,1 & 254,0 \\
\hline Birds of all kinds & 67037,7 & 74870,1 & 86374,8 & 87859,7 & 90131,8 \\
\hline \multicolumn{7}{|c|}{ Dehkan farms, \% } \\
\hline Cattle & 94,1 & 93,6 & 93,5 & 93,2 & 92,8 \\
\hline incl. cows & 94,5 & 94,2 & 94,1 & 93,6 & 93,2 \\
\hline Sheep and goats & 83,8 & 84,2 & 83,6 & 82,5 & 81,4 \\
\hline Horses & 85,0 & 82,2 & 80,0 & 77,4 & 76,3 \\
\hline Birds of all kinds & 62,0 & 59,0 & 55,2 & 58,7 & 58,9 \\
\hline \multicolumn{7}{|c|}{ Farming enterprises, \% } \\
\hline Cattle & 4,9 & 5,2 & 5,5 & 5,9 \\
\hline incl. cows & 4,6 & 4,8 & 5,0 & 5,4 & 5,8 \\
\hline Sheep and goats & 7,7 & 10,5 & 11,4 & 12,3 & 13,3 \\
\hline Horses & 9,5 & 14,1 & 16,0 & 17,8 & 19,1 \\
\hline Birds of all kinds & 11,6 & 12,4 & 14,1 & 14,0 & 14,8 \\
\hline \multicolumn{7}{|l|}{ Organizations engaged in agricultural activities, \% } \\
\hline
\end{tabular}




\begin{tabular}{|l|c|c|c|c|c|}
\hline Cattle & 1,2 & 1,5 & 1,3 & 1,3 & 1,3 \\
\hline incl. cows & 0,9 & 1,0 & 0,9 & 1,0 & 1,0 \\
\hline Sheep and goats & 8,4 & 5,3 & 5,0 & 5,2 & 5,3 \\
\hline Horses & 5,5 & 3,7 & 4,0 & 4,8 & 4,6 \\
\hline Birds of all kinds & 26,4 & 28,6 & 30,7 & 27,3 & 26,3 \\
\hline
\end{tabular}

The efficiency and profitability of stock-raising is directly dependent on the strength of the feed structure, which includes the stages of production, storage and consumption of feed mixtures for birds and animals. Most of the farms and dekhkan farms do not have their own feed base, $75 \%$ of dekhkans and $30 \%$ of farms have to buy feed for their stock-raising. At the same time, stock-raising breeders most often buy grasses and hay, fodder corn, and other feeds are purchased rarely and in small quantities due to their high cost. Considering that the recommended ration for feeding cattle should consist of $15-20 \%$ of combined feed, and this norm is not met in most farms and dekhkan households, problems arise with low productivity of animals. [3]

According to the State Statistics Committee, the area of forage crops in Uzbekistan decreased from 333.5 thousand hectares in 2016 to 267.6 thousand hectares in 2019, i.e. 1.2 times, which was the main reason for the reduction in the production of some forage crops in the same years. In particular, the production of corn for silage, green forage and haylage decreased 1.3 times in 2019 compared to 2016, fodder root crops - 1.5 times, perennial grasses - 1.6 times (Table 3). The decrease in the area under grain and cotton also led to a decrease in the remains of raw materials for the fodder base, in particular, cotton meal, husks and feed mixtures.

Table 3. Dynamics of indicators of forage crops [7]

\begin{tabular}{|c|c|c|c|c|c|}
\hline & 2016 & 2017 & 2018 & 2019 & $\begin{array}{l}\text { In } 2019 \text { in } \\
\text { relation to } \\
2016, \text { times }\end{array}$ \\
\hline $\begin{array}{l}\text { Area of forage } \\
\text { crops, thousand } \\
\text { hectares }\end{array}$ & 333,5 & 243,4 & 242,7 & 267,6 & $-1,2$ \\
\hline \multicolumn{6}{|c|}{ Production of feed products, thousand tons } \\
\hline $\begin{array}{l}\text { Corn for silage, } \\
\text { green forage and } \\
\text { haylage }\end{array}$ & 4366,4 & 2775,7 & 2782,9 & 3253,3 & $-1,3$ \\
\hline Fodder root crops & 213,1 & 180,6 & 120,5 & 140,5 & $-1,5$ \\
\hline $\begin{array}{l}\text { Annual grasses for } \\
\text { hay }\end{array}$ & 746,5 & 850,1 & 778,8 & 824,3 & $+1,1$ \\
\hline $\begin{array}{l}\text { Perennial grasses } \\
\text { (sown in the } \\
\text { current year and } \\
\text { past years) }\end{array}$ & 1358,2 & 851,1 & 705,8 & 854,5 & $-1,6$ \\
\hline
\end{tabular}

In addition to the aforementioned, the insufficient supply of fodder is associated with the ineffective use of land allocated for fodder crops. At a time when it is possible to grow up to 100 centners of feed wheat on one hectare, the actual figure does not even reach 50 centners. Low productivity of natural pasture and hayfields, which serve as the main source of coarse green fodder, is caused by the insufficient cultural and technical condition of the land, an ineffective extensive system for the development of grassland farming. [6]

In general, the problems of feed production are associated with the fact that:

- fodder crops are often grown on lands of poor quality, which leads to their low productivity;

- fodder crop rotations are not used on farms, which would provide the necessary structure and rotation of crops and would contribute to an increase in soil fertility; 
- seed production of forage crops is poorly developed;

- low equipment with special agricultural machinery and fuels and lubricants;

- insufficient level of application of mineral fertilizers, etc.

The peculiarities of livestock farming determine another key factor in this area - the development of the infrastructure of services for livestock producers. Providing proper veterinary services and improving the breed remains one of the pressing problems in stockraising. The value of improving the breed can be expressed in specific numbers: for example, local beef cattle, at a cost of 20 thousand soums for their fattening, gains 900 grams of live weight or 500 grams of meat per day, and pedigreed types - 1 kilogram 600 grams of live weight, from which you can get 900 grams of meat. Here it is worth mentioning the problem of keeping thoroughbred cattle: the productivity of an imported thoroughbred cow, which is capable of producing 35-40 liters on average, is reduced to 20-25 liters (at best) due to improper care and poor quality maintenance.

Research in this direction has shown that the entities providing services do not have the opportunity to fully meet the demand of all dekhkan and private farms for animal health services. This is mainly due to the following:

- underdeveloped infrastructure that provides an effective system of relationships for producers and service providers, including veterinary services;

- the geographical remoteness of stock-raising farms in relation to service centers (problems with time, with transport costs and transport communications), which prevents the timely and efficient provision of services by these units;

- the lack of specialists in the correct feeding of livestock, the provision of modern veterinary services and, as a result, the low quality of services for stock-raising farms, etc. [3]

It should also be noted that the low solvency of farms, the lack of opportunities and incentives for dekhkan farms to improve the quality of livestock products and improve livestock management; a high degree of wear and tear of most livestock facilities (cowsheds, calves, etc.) and outdated equipment and technologies for keeping livestock; poor use of modern innovative technologies, technical means, zootechnical methods, food rations, digital technology and information technology in the livestock industry are factors that hinder the implementation and development of innovations in the agricultural industry.

\section{Conclusions}

An important task in the development of stock-raising is to improve the quality of products. This is facilitated by selection methods and scientifically grounded norms of animal feeding, improved technical equipment of farms, material incentives for workers to improve product quality.

An effective solution to fodder production can be intensification with the introduction of measures to improve the condition of fodder areas, reclamation, irrigation work, improve seed production with the breeding of fodder crops resistant to diseases and pests, and introduce fundamentally new methods of processing, procurement, storage and transportation of fodder.

An increase in the productivity of animals is possible through the development of breeding in the republic, the establishment of an artificial insemination system and an increase in the number of pedigree cattle imported from abroad. In turn, the introduction of the latest technology, equipment, original stock of animals into production is possible by strengthening the interaction of science with production, using high scientific potential of the republic. 
An important factor in ensuring the effectiveness of the development of the stock-raising industry will be the timely implementation of the tasks provided by the Strategy for the Development of Agriculture of the Republic of Uzbekistan for 2020-2030, including [1]:

stimulating cooperation between agricultural producers and developing measures for their integration into modern value chains in the domestic and international markets;

the formation of associations (cooperatives and others), coordinating the production of agricultural products and services provided in this area;

ensuring cooperation between agricultural associations, farms and dekhkan farms with industrial processing enterprises (including clusters).

\section{References}

1. Decree of the President of the Republic of Uzbekistan dated on October 23, 2019 N UP5853 "On approval of the Strategy for the development of agriculture of the Republic of Uzbekistan for 2020-2030".

2. N.A. Ashurmetova, M.T. Ergashboeva, Bulletin of Science and Education, 12 (90), 38$43(2020)$

3. U.M. Kuchchiev, Improving the scientific and methodological foundations for the development of the service sector for livestock farms, Abstract of a doctoral dissertation (DSc) in economic sciences (Tashkent, 2020)

4. Yu. Naumov, I. Pugach, Problems and prospects for the development of stock-raising in Uzbekistan (Discussion Paper, 188, 2019)

5. M.Kh. Saidov, N.A. Ashurmetova, State support of entrepreneurship during the coronavirus pandemic, Collection of materials of the 6th Int. scientific and practical. conf. "Formation and development of entrepreneurship in Russia: history, modernity and prospects", Smolensk State University, 206-214 (2020)

6. Feasibility study of the project "Development of the stock-raising sector in the Republic of Uzbekistan" with the participation of MAR and MBRR, (Tashkent, 2017)

7. Agriculture of Uzbekistan, Statistical collection, 2016-2020 (Tashkent, 2021) www.stat.uz

8. http://www.fao.org 